\title{
3-Years Post-Operative Outcome of a Recipient of Pulmonary Valve Homograft Originating from a Heart Transplant Patient in Singapore
}

Heng Wee Ling*, Tan Ju Le, Lim Chong Hee and Lim Yeong Phang

National Heart Centre, Singapore

\begin{abstract}
At the National Cardiovascular Homograft Bank (NCHB), heart transplant patients represent an important source of donor pool. In this case study, we highlight our recipient with the longest follow-up, who was implanted with a pulmonary valve donated by a heart transplant patient three years ago, and his post-implantation outcome. The live donor's diagnosis and quality of the donated heart valve are also discussed. This is used as a backdrop to explore some risk factors affecting homograft durability and NCHB's attempts to address the known significant risk factors in homograft processing and storage to maintain the high quality of our homografts.
\end{abstract}

Keywords: Cardiovascular homograft; Heart valve; Post-operative outcome; Living donor; Heart transplant patient

\section{Introduction}

Cardiovascular homograft banking started its operations in February 2008. Its objective is to offer a local source of cryopreserved human heart valves and vascular tissues for transplantation nationwide.

Human heart valves are the replacement of choice in complex left and right ventricular outflow tract reconstructions in children and adults. It is also the preferred choice for replacement in patients with small aortic roots or aortic root endocarditis, patients requiring aortoventriculoplasties, patients whose long-term post-operative anticoagulation therapy is contraindicated, children, women of childbearing age and adults with physically demanding occupations.

While most of NCHB's donors are deceased, who consent to tissue donation via the Medical (Therapy, Education and Research) Act (MTERA) in Singapore, heart transplant recipients are also approached for the donation of their native heart valves. In this article, we present a case study of a pulmonary valve recipient and his 3 years post-operative outcome. A retrospective study of the diagnosis and the quality of the donated heart valve is performed.

\section{Case Report}

\section{Donor background}

The donor is a 49-year-old male. He suffered from left main coronary artery thrombosis, which led to ST-segment elevation myocardial infarction. He developed cardiogenic shock and required high-dose of inotropic and intra-aortic balloon pump support. Extracorporeal membrane oxygenation was instituted. As there is no evidence of myocardial recovery, he was eventually implanted with a left ventricular assist device as a bridge to heart transplant.

Result of the latest echocardiogram performed a month prior to his heart transplant showed that the pulmonary valve leaflets appeared normal in structure and function, with no regurgitation. Additionally, a comprehensive set of assessment was performed to evaluate the quality of his aortic and pulmonary valves. This included a review of the two-dimensional Transthoracic Echocardiogram (TTE), competency test, visual inspection of the valves during tissue dissection, and histopathological review.

\section{Preparation of homograft}

To preserve cell viability, the heart valve block, comprising of aortic valve, pulmonary valve and mitral valve leaflet was excised from the explanted heart. It was then immersed in cold saline at a temperature of $1^{\circ} \mathrm{C}$ to $10^{\circ} \mathrm{C}$ during dissection and transportation to NCHB laboratory.

At the laboratory, further separation of aortic and pulmonary valves occurred in the laminar flow hood. The valve annulus and length of the conduits were measured. Competency test was performed by flushing saline, with the help of a $20 \mathrm{ml}$ syringe, through the valves. Pulmonary valve was competent, with no leakage and regurgitation as it inflated. Furthermore, no trauma, calcification or fenestration in the valve leaflets was detected during visual inspection.

The pulmonary homograft was then decontaminated in tissue medium 199 (M199) containing $50 \mathrm{IU} / \mathrm{mL}$ of penicillin and $50 \mathrm{ug} / \mathrm{mL}$ of streptomycin, and incubated at $37^{\circ} \mathrm{C}$ for 6 hours. Subsequently, it was preserved in freeze solution, consisting of $10 \%$ dimethyl sulfoxide in M199. Finally, the pulmonary homograft was packaged with freeze solution in double layers of cryogenic bag. Controlled rate freezing was performed, at the cooling rate of approximately $1 \mathrm{C}$ per minute. Thereafter, it was transferred to a quarantine liquid nitrogen storage tank.

\section{Infectious diseases, microbiological testing and histopathological examination}

The donor had no systemic infection or history of malignancy. $\mathrm{He}$ was also tested non-reactive for hepatitis $\mathrm{B}$ and $\mathrm{C}$, human immunodeficiency virus, syphilis and human T-lymphotrophic virus. Histopathological examination of his heart tissues revealed massive recent acute myocardial infarction in the territory of the left coronary circulation. There was also extensive advanced atherosclerosis of coronary arteries, with evidence of previous stenting and in-stent restenosis.

*Corresponding author: Heng Wee Ling, National Cardiovascular Homograft Bank, National Heart Centre Singapore, Mistri Wing, 17 Third Hospital Avenue, Singapore 168752, Tel: 6436 7577; Fax: 6221 0019; E-mail: heng.wee.ling@nhcs.com.sg

Received October 16, 2012; Accepted December 17, 2012; Published December 19,2012

Citation: Heng WL, Tan JL, Lim CH, Lim YP (2012) 3-Years Post-Operative Outcome of a Recipient of Pulmonary Valve Homograft Originating from a Hear Transplant Patient in Singapore. J Clin Case Rep 2:230. doi:10.4172/2165 7920.1000230

Copyright: @ 2012 Heng WL, et al. This is an open-access article distributed under the terms of the Creative Commons Attribution License, which permits unrestricted use, distribution, and reproduction in any medium, provided the original author and source are credited. 
Routine aerobic, anaerobic and fungal cultures of the homograft were performed. This was done by sending tissue and solution specimens collected during post-recovery and post-antibiotic incubation phases. The pulmonary homograft revealed negative microbiological and fungal results. After the NCHB Medical Director reviewed the donor's infectious diseases, microbiological cultures and histopathological results, the homograft was determined to be suitable for implantation and transferred to the clinical liquid nitrogen storage tank. It was stored for 256 days from the date of cryopreservation of homograft to the date of implantation. The processes were comprehensively described in our earlier article [1].

\section{Recipient information}

The recipient of the pulmonary valve was a 26-year-old male. He was diagnosed with Tetralogy of Fallot, which had been repaired with residual supra-valvular pulmonary trunk stenosis. Seven months prior to homograft implantation, his TTE showed severe pulmonary regurgitation and mild supra-pulmonary stenosis with mean gradient of $23 \mathrm{mmHg}$. There was no remnant pulmonary valve seen. Cardiac magnetic resonance imaging result performed a month prior to operation was consistent with free pulmonary regurgitation. Right ventricle was moderately dilated, with mildly impaired systolic function and restrictive right ventricular physiology. Right ventricular outflow tract aneurysm was present. Left ventricle was normal in size and systolic function. Pulmonary annulus was dilated, with mild narrowing of main and left pulmonary artery.

To correct his condition, the recipient underwent pulmonary homograft implantation. The package containing the homograft was thawed in warm saline and aseptically rinsed in Ringer's Lactate for 15 minutes. The homograft was then sewn in as an in-lay graft with an equine pericardial patch. The recipient did well post-surgery. There was no immediate complication and he was transferred to the general ward 3 days post-operatively.

TTE performed 4 days post-operatively showed satisfactory mean gradient of $17 \mathrm{mmHg}$ across the homograft after implantation. The size of right ventricle was reduced. Pulmonary valve leaflets from the homograft were normal in structure, function and appeared stable. There was trivial pulmonary regurgitation observed. The recipient was well and afebrile throughout his stay in the ward. He was discharged 5 days after operation.

He is currently under follow-up with our hospital's cardiologist. Annual echocardiographic follow-up post-operation showed mildly dilated right ventricle. Valve function remained normal and homograft appeared stable. There was mild supra-valvular pulmonary stenosis with mean gradient $26 \mathrm{mmHg}$ and mild pulmonary regurgitation. $\mathrm{He}$ is currently well, asymptomatic and experiences no adverse reaction since his operation.

\section{Discussion}

In Singapore, the donation of cardiovascular homograft is legislated under MTERA, a voluntary donation act. Due to bereavement, cultural reasons and/or misconceptions, there is generally higher resistance among our Asian society towards tissue donation, although this trend is slowly changing. As a result, our consent rate remains dismal, with $58.6 \%$ of non-consent among suitable deceased donors for cardiovascular homografts. On contrary, the consent rate for live donors is $100 \%$. Till date, heart transplant patients represent $27.9 \%$ of our donors.
Interestingly, many tissue banks do not store heart valves from native hearts of heart transplant patients, although some used to recover valves from live donors. However, this practice was discontinued in some due to tissue or process-related reasons. These include inferior tissue quality, complicated procurement procedure and higher possibility of recovering only one functional valve, which impacts the cost-effectiveness in processing and storage. According to our bank's experience, only $33.3 \%$ of native hearts from live donors yielded both functional aortic and pulmonary valves upon examination during tissue dissection, as compared to $71.4 \%$ from deceased donors. Moreover, the main disadvantage of valves recovered from live donors is the shorter conduit length, which may present more limitation during implantation. Surgeons may also require additional pericardium patches for conduit extension during implantation.

Currently in NCHB, 10 recipients had been implanted with heart valves from live donors. 9 recipients, which include the one featured in this case report, are currently doing well on regular follow-ups. One passed away due to non-homograft related cause. Homograft failure is defined as homograft dilatation or homograft replacement, which occurred if the homograft gradient was $>50 \mathrm{mmHg}$ [2]. Till date, there is no case of homograft failure, explantation, endocarditis, adverse reaction, thromboembolic event, redo-operation or mortality due to homograft-related complication.

For the recipient featured, the increase in gradient and the grade of pulmonary regurgitation, from trivial to mild, over the post-operative echocardiographic follow-ups may have been indicative of a start in the homograft degenerative process. However, mild incompetence of the homograft can still be considered haemodynamically insignificant [3], since degeneration of valve is defined as moderate or severe regurgitation or stenosis [4]. The increase in gradient can also be attributed to fibrosis and scarring at the anastomotic site between the pulmonary homograft and native pulmonary artery in some cases.

A study by O' Brien et al. concluded that $75 \%$ to $85 \%$ of their recipients, who were implanted with aortic valves from heart transplant patients, multi-organ donors or autopsy valves from donor death, were free of structural deterioration at 15 years, and $70 \%$ to $75 \%$ at 20 years [5]. Another study by Troost et al. also presented the mean event-free survival time for first homograft was 14.6 years [2]. The longevity of homografts is adversely affected by many risk factors, such as older age of donor [3,4,6-10], female donors [4,9], longer donor ischemic time $[8,11]$, preservation technique [5,7], shorter cryopreservation time $[9,12]$, young age of recipient $[2-5,7,11,13]$, significant homograft size mismatch $[5,8,10,11,14]$, complexity of underlying cardiac condition [2], preoperative pulmonary hypertension $[10,13]$, type of homograft implanted $[2,4,8,9,11,13]$, operation technique $[11,14]$, and complexity of operation [4]. These risk factors may lead to homograft failure, by causing geometric distortion after the insertion of homograft, a loss of radial extensibility, degeneration of the valve leaflets characterised by leaflet thinning, tearing and perforation, or progressive aortic root dilatation [15].

Although heart transplant patients are an invaluable source of donors, it is extremely critical to perform a proper donor assessment, inspect the tissues and test their valves for competency prior to recovery, due to their pre-existing cardiac conditions. Live donors whose hearts failed due to viral or idiopathic cardiomyopathy and cardiac sarcoidosis are excluded. Donor age criteria is established at $\leq 65$ years, as there is a higher risk of degeneration for homografts recovered from a donor of $>65$ years [4]. This increase in risk is presumably associated with 
Citation: Heng WL, Tan JL, Lim CH, Lim YP (2012) 3-Years Post-Operative Outcome of a Recipient of Pulmonary Valve Homograft Originating from a Heart Transplant Patient in Singapore. J Clin Case Rep 2:230. doi:10.4172/2165-7920.1000230

Page 3 of 3

structural changes in the valve leaflets that are known to occur with aging and pre-implantation loss of radial extensibility of the homograft [15].

In addition, $\mathrm{NCHB}$ attempts to eliminate the known risk factors as discussed earlier, from our homograft processing and storage procedures. These include:

1. The use of cryopreservation technique: Antibiotic-disinfected cryopreserved homografts have demonstrated excellent freedom from structural deterioration $[5,7,14]$ due to superior preservation of tissue matrix.

2. To strictly abide to the time limit of no more than 48 hours for the total donor ischaemic time, as stipulated by the American Association of Tissue Banks standard [16]. This reduces the extent of injury to the homograft, as a result of reparative and immune response, which will consequently lead to less rapid failure [11].

3. To abide to the duration of homograft recovery-tocryopreservation of $>24$ hours. Cryopreservation is believed to retain cell viability and reduce antigenicity of the homograft. Although Baskett et al. discovered that short cryopreservation duration of $<24$ hours was associated with failure [12] probably due to increased immunogenicity, this finding was not supported by Tweddell et al., who concluded that the duration of cryopreservation, is not a significant factor [11]. This inconsistency in findings appears to demonstrate a controversy on the significance of immunogenicity in homograft failure.

Homograft degeneration and failure is a complex and multifactorial event. Therefore, its degeneration cannot be attributed to mere oversimplified explanation of any few risk factors. Despite a gradual degeneration which is inevitable for all human tissues, homograft function over time and recipient survival were excellent [11]. However, due to their limited durability, homografts are not permanent replacements, especially for younger recipients. As far as we know, there is no literature which specifically explores the relationship of implantation of homografts from heart transplant patients and the durability of such homografts. As all our recipients are $\leq 3$ years eventfree post-operation, it is still preliminary to suggest if homograft from a live donor is a risk factor affecting its durability, considering that there are banks which discontinue the storage of such homografts. In our context, such homografts are immediately processed in our facility, and the total ischaemic time is shorter as compared to non-beating heart or multi-organ donors, which recovery is performed in other hospitals. Therefore on contrary, we feel that the quality of such homografts may be better, though longer term follow-up is necessary to establish this.

\section{Acknowledgement}

We are grateful to Ministry of Health Singapore for the Health Service Development Programme (HSDP) grant in support of this programme, Lisa Sparks, Kerk Ka Lee and Tracy Seck for their advices.

\section{References}

1. Heng WL, Seck T, Tay CP, Chua A, Song C, et al. (2012) Homograft banking in Singapore: two years of cardiovascular tissue banking in Southeast Asia. Cell Tissue Bank.

2. Troost E, Meyns B, Daenen W, Van De Werf F, Gewillig M, et al. (2007) Homograft survival after Tetralogy of Fallot repair: determinants of accelerated homograft degeneration. Eur Heart J 28: 2503-2509.

3. Barratt-Boyes BG, Roche AH, Subramanyan R, Pemberton JR, Whitlock RM (1987) Long-term follow-up of patients with the antibiotic-sterilized aortic homograft valve inserted freehand in the aortic position. Circulation 75: 768777 .
4. Hasnat K, Birks EJ, Liddicoat J, Hon JKF, Edwards S, et al. (1999) Patient Outcome and Valve Performance Following a Second Aortic Valve Homograft Replacement. Circulation 100: II-42-II-47.

5. O'Brien MF, Stafford EG, Gardner MA, Pohlner PG, Tesar PJ, et al. (1995) Allograft aortic valve replacement: long-term follow-up. Ann Thorac Surg 60: S65-70.

6. Grocott-Mason RM, Lund O, Elwidaa H, Mazhar R, Chandrasakeran V, et al. (2000) Long-term results after aortic valve replacement in patients with congestive heart failure. Homografts vs prosthetic valves. Eur Heart J 21: 1698-1707.

7. O'Brien MF, Harrocks S, Stafford EG, Gardner MA, Pohlner PG, et al. (2001) The homograft aortic valve: A 29 -year, $99.3 \%$ follow up of 1,022 valve replacements. J Heart Valve Dis 10: 334-344.

8. Shaddy RE, Hawkins JA (2002) Immunology and failure of valved allografts in children. Ann Thorac Surg 74: 1271-1275.

9. Ryan WH, Herbert MA, Dewey TM, Agarwal S, Ryan AL, et al. (2006) The occurrence of postoperative pulmonary homograft stenosis in adult patients undergoing the Ross procedure. J Heart Valve Dis 15: 108-113.

10. Kalfa DM, Loundou A, Nouaille de Gorce Y, Fraisse A, Metras DR, et al. (2012) Pulmonary position cryopreserved homograft in non-Ross patients: how to improve the results? Eur J Cardiothorac Surg 42: 981-987.

11. Tweddell JS, Pelech AN, Frommelt PC, Mussatto KA, Wyman JD, et al. (2000) Factors affecting longevity of homograft valves used in right ventricular outflow tract reconstruction for congenital heart disease. Circulation 102: III-I30-III-135.

12. Baskett RJ, Ross DB, Nanton MA, Murphy DA (1996) Factors in the early failure of cryopreserved homograft pulmonary valves in children: preserved immunogenicity? J Thorac Cardiovasc Surg 112: 1170-1178.

13. Niwaya K, Knott-Craig CJ, Lane MM, Chandrasekaren K, Overholt ED, et al. (1999) Cryopreserved homograft valves in the pulmonary position: risk analysis for intermediate-term failure. J Thorac Cardiovasc Surg 117: 141-146.

14. Eriksson MJ, Källner G, Rosfors S, Ivert T, Brodin L (1998) Hemodynamic performance of cryopreserved aortic homograft valves during midterm followup. J Am Coll Cardiol 32: 1002-1008.

15. McGriffin DC, Kirklin JK (2005) University of Alabama at Birmingham series. In Hopkins RA (ed.). Cardiac reconstructions with allograft tissues.

16. American Association of Tissue Banks (2008) Standards for Tissue Banking (13thedn). 